Vols. LXV-LXVI, January-June, July-December, 2019

ISSN 1607-2278 (Print), DOI : https://doi.org/10.3329/pp.v63i1-2.55958

\section{VOLTAIRE'S INFLUENCE IN THE MIND OF THE REVOLUTIONARIES OF THE FRENCH REVOLUTION}

\section{Lukna Yasmin*}

\begin{abstract}
18th century Europe had produced many enlightened scholars. Voltaire was one of them. French Revolution was a great chapter in the history of France. It had made a new era in France. This epoch-making event had brought many significant changes in various sectors in France. It occurred in France but it not only changed France, it brought about a change in the whole world later on. It started in 1789 and continued till 1799. French philosopher Voltaire died in 1778. But his influence was profound. He had contributed to bring revolutionary changes in French church and governmental system through his writings. French revolutionaries were inspired by his wonderful literary works. French revolution and Voltaire are inseparably connected. In this article an attempt has been made to review the impact of Voltaire's write-up in the mind of the French revolutionaries.
\end{abstract}

This article has been written on the basis of the primary sources and the information's found in the world famous

*Associate Professor, Department of History, University of Dhaka Email: luknayasmin@gmail.com historical books. Primary sources are Voltaire's relevant writeups such as 'Letters Philosophiques', 'Treatise on Tolerance' and 'The Dictionnaire Philosophique.'

French Revolution had started in the year of 1789 and continued till 1799. It had brought radical changes in different sectors in France. Before French revolution French parliament was known as Estates-General. (Phillip Lee Ralph and others: 196-216, R.R. Palmer and others: 343, Mark Kishlansky and others: 616). The last election of Estates-General was held in 1614. In 1789, the election of Estates-General was held after one hundred and seventy five years. Estates-General was three chambered parliament. These chambers were the First Estate, the Second Estate and the Third Estate. The representatives of the Clergy were the members of the First Estate, the representatives of the Nobility were the members of the Second Estate and the representatives of the Common people excluding clergy and nobility were the members of the Third Estate (Shepard B. Clough and others: 370). If we analyze the early history of the French Estates-General, then we can see that the Third Estate in Estates-General was not in honorable position. They had no influence in the decision making process. They were nominal members of the Estates-General. Members of the Third Estate were extremely dominated by the nobility and clergy. During decision making process the work of the representatives of the Third Estate was just to listen, to receive, to give approval and to execute the work commanded by the clergy and nobility. So First Estate and Second Estate were too much powerful and influential jointly to fulfill their any wish. In the Estates-General of 1789 the members of the Third Estate were the majority. So, this Estates-General was not like earlier Estates-General in France. Approximately twelve hundred and 
fourteen representatives were elected in that epoch making election. Among them approximately six hundred and twenty one members were in the Third Estate. Among them most of the members were well educated and ambitious. They were very much eager to change their fortune. They aspired to become something (Hays: 488-491). They were enlightened because they were earnest reader of Voltaire, Montesquieu and Rousseau's literatures. They were desirous to read Voltaire's write-up. Voltaire (21st November,1694-30th May,1778), Montesquieu (18th January, 1689-10th February, 1755) and Jean-Jacques Rousseau (28th June, 1712-2nd July, 1778) were the prominent philosophers in the eighteenth century Europe. The representatives of the Third Estate or French revolutionaries were great admirer of them. Writings of the above mentioned philosophers had created immense impulses in the minds of the representatives of the Third Estate. In this article an attempt has been made to review the influence of Voltaire's write-up in the mind of the revolutionaries of the French revolution.

Voltaire is world renowned French philosopher, litterateur, writer, playwright and historian. He was endowed with many good qualities. He was fearless and outspoken writer. He had written fearlessly against religious superstitions which were expected to accept without any argument in that time. He had criticized daringly about the mischievous activities of the church officials of France in the name of the religion. French revolutionaries were fond of his write-up (R.R. Palmer and others: 302). Voltaire's write-up had made a profound influence in their mind which has been analyzed in this article.

Voltaire was vigorous, energetic, spirited, audacious and daring writer. The prime characteristic of his writings was heedless bravery. From his young age he had started his writing heedlessly. His write-ups were full of the wit and wisdom and were mainly satirical. He adopted a style called 'satire'. Satire was his way of criticizing in which he had used humour to show something's or somebody's weakness or fault. By his satirical writing he argued strongly for or against some people or some institutions. (Mark Kishlansky and others:580, R.R. Palmer and others: 302 )

In the year of 1778 Voltaire breathed his last at the age of 84. But he was alive in his courageous write-ups which had indicated the necessity for reforming church administration in France. Revolutionaries were highly engrossed by the revolutionary views of Voltaire who was one of the greatest philosophers of all time. (Philip Lee Ralph and others: 153)

During the course of his life Voltaire had written on history, he had done huge historical works. He had multifaceted literary career. His main works on history are 'History of Charles XII, king of Sweden' in 1751, ' 'The age of Louise XIV' in 1751, 'The age of Louise XV' in 1752, 'Annals of the Empire, Charlemagne - Henry VII, vol. i' in 1754, 'The age of Louis of Bavaria to Ferdinand II,' vol. ii in 1754, 'Essays on Universal history, the manners and spirit of nations' in 1756, 'History of the Russian Empire under Peter the Great,' Vol. I in 1759 and vol. II in 1763, Discourse on the Universal history in 1682. He had also written an essay titled 'Essay upon the civil wars in France'. As a litterateur and historian, he had written an epic poem 'La Henriada' in 1723 which is based on the life of the great king Henry IV of France; this is his extraordinary literary composition in which he had glorified Henry IV of France for his immense success for establishing religious harmony in France by issuing Edict of Nantes (1598). 
(William Doyle: 50, Hayes, Carlton J.H:397,406, Alfred Cobban: 119-125, Sheppard B. Clough, David L. Hick David Brandenburg Peter Gay: 605)

As a historian, he did not follow his contemporary tradition to describe military and diplomatic course of incidents. He emphatically reviewed various aspects of society and advancements of human being in the field of arts and sciences. In 1747, he published his philosophical novella 'Zadig oul le Destinee' or 'The Book of Fate' in which he had written a story of Zadig, who was a philosopher in Babylonia in ancient period. This book had touched the hearts of the revolutionaries and they were enlightened by this book. Voltaire's book 'Candide' had great impact in the hearts of the enlightened readers of France who were eager to change existing system in France. In the eyes of many critiques this book was one of the best literary works of western literature (Aldridge, Alfred Owen: 260). When 'Candide' was published in 1759, both secular and religious authorities had gone against Voltaire. Because this book had mocked church and government very sharply. In the month of February, 1759, it was banned by the French government. But despite this opposition and restriction 'Candide' had become bestselling book (Alfred Cobban: 85, Mason, Haydn: 13-15). Roman Catholic Church listed his book in its list of forbidden books (Williams, David: 1-3). Through this book he had created churning in the minds of the enlightened class of France. By reading Candide highly educated class of France had felt a stirring of discontent about church officials and French government. During French revolution French revolutionaries had done vast reforms in the French church administration. Because its appeal had reached to the hearts of the revolutionaries. (Alfred Cobban: 85, Ayer, AJ, Voltaire: 139, Mark Kishlansky, Patrick Geary, Patricia O’Brien: 581, Philip Lee Ralph, Robert E. Lerner, Standish Meacham, Alan T. Wood, Richard W. Hull, Edward McNall Burns:154)

French revolutionaries were highly influenced by his book titled 'Letters concerning the English Nation' (R.R. Palmer and others: 302). Voltaire had written this book by using his experiences, observations and knowledge's gained in England during his stay in that well governed country. Very important part of his life had evolved around England. England had brought many positive changes in his life. He was severely harassed and punished for his satirical literary works in France. He was sent in 'Bastille Fort' two times for his satirical writings against French nobility and also French corrupted governmental system. Then French government considered his satirical works as a crime against French governmental system. As he had become troubled by the furious actions of French royal authority, so he had taken a decision to give up his given name 'Francois Marie Arouet' and adopt a pseudonym 'Voltaire' by which name he had become world renowned philosopher. In the year of 1718 he had started to write under a pseudonym 'Voltaire' (Mark Kishlansky and others: 580). But despite taking pseudonym he could not be relieved from harassment and oppression. He had been afflicted by the tormenting noble class in Paris. As a result of quarrel with a member of the second estate in French society, though he was not guilty, Letter de Cachet had been issued against him and Voltaire was thrown away in 'Bastille Fort' for an indefinite period. To avoid this suffering he had prayed to leave France and to stay in England and his appeal was granted by the authority concerned. On $2^{\text {nd }}$ May in 1726 , he was given chance 
to leave Paris and to go to England. (Alfred Cobban: 119, Mark Kishlansky and others: 580, Robert Ergang: 634). He had a well-wisher in South London who was a diplomat and also engaged in business. After reaching England he got safe shelter in his well-wisher's residence. When he started his exiled life in London, in that time George the III was the king of England and Robert Walpole was the Premier of the country. Though Voltaire's banishment in England was a punishment for him, this banishment had come to his life as blessings. This banishment had brought precious experiences for him by which he had become a world renowned great philosopher. He stayed in England for two and a half years. During his stay he was charmed by the good governance of England. The people of England were enjoying religious freedom and freedom of speech in that time. He was enchanted by the constitutional monarchy of England which was protecting people's right nicely. He had friendly terms with many people in high society of England. He was illuminated by the constitutional monarchy; he was enlightened by good governance of England. The way the rulers of England had been governing, Voltaire was motivated and awakened. An opportunity had come for him to compare constitutional monarchy of England and absolute monarchy of France (Alfred Cobban: 119). He had realized that British system of government was elevated and polished. He was amazed by constitutional monarchy which had kept England under discipline. He did not witness such a wonderful advanced society and orderliness in his own country's ruling system. Voltaire had expressed his fascination about society and politics of England in this book. In this book he had praised the attitude of government of England to their people, their good governance, literary and scientific advancement. He was too much charmed about the freedom of expressions and religious freedom of the people of England. (R.R. Palmer and others: 303, Alfred Cobban: 120). He had written his high evaluations about England in this book in letter form. This book was a compilation of twenty four letters. Voltaire had written this letters from the perspective of a foreigner. In the following year he had published this book in French language. In French language this book was titled as 'Letters Philosophiques.' When it had appeared in French language in France, French government had learnt about the content of this book. As Voltaire highly praised about British constitutional monarchy and religious freedom and freedom of expressions, so French government did not tolerate the content of this book. He reviewed political system, religious freedom, trade system, English practice of inoculation, literature, royal society of London and various things about England in his twenty four letters. By reading this book French enlightened class had gained knowledge about political system and also parliamentary system, their tolerant society and constitutional monarchy of England. By praising British constitutional monarchy Voltaire had criticized French absolute monarchy. By comparing constitutional monarchy of England and absolute monarchy of France, he had said that British system of government was better than that of French absolute monarchy (Prafulla Kumar Chakrabarti: 27). French government did not like it and they had considered this book as an attack for French government and had banned this book. French bourgeois class was the real makers of the French revolution. They had come to power through the election of the EstatesGeneral of 1789 and they had declared Estates-General as 'National Assembly.' On $9^{\mathrm{h}}$ July, 1789, National Assembly had 
declared itself as 'National Constituent Assembly' (Philip Lee Ralph: 202). In 1791 National Constituent Assembly had drawn up 'French Constitution of 1791' which was the first constitution of France. Because France had no constitution till 1791 (R.R. Palmer and others: 358). By this constitution revolutionaries had abolished French absolute monarchy and introduced constitutional monarchy on Ist October, 1791. So this is easily understandable that French revolutionary leaders especially constitution makers were highly influenced by Voltaire's book. (A. Goodwin: 681, Robert Ergang: 634, R.R. Palmer, Joel Colton, Lioyd Kramer: 358, Mark Kishlansky, Patrick Geary, Patricia O’Brien: 579, 580, Philip Lee Ralph, Robert E. Lerner, Standish Meacham, Alan T. Wood, Richard W. Hull, Edward McNall Burns: 154, Robert Ergang: 632-637)

In 1763, Voltaire published his book titled Treatise on Tolerance. In this book he had written in favor of religious tolerance and against religious dogma and fanaticism (R.R. Palmer and others: 303). French revolutionaries had become enkindled by the content of this book. This book infused Great Spirit in the hearts of the French revolutionaries. In this book he presented an authentic picture that how religious tolerance had brought peace and stability in different country and how religious intolerance had caused immense sufferings for the society. He criticized about the 'Revocation of the Edict of Nantes' by which Louis XIV of France had cancelled 'Edict of Nantes of 1598.' In 1598, 'Edict of Nantes' had established religious freedom of French Protestants and had ended the 'Wars of Religion.' Mentionable that 'Wars of Religion' had continued for thirty six years in France (Alfred Cobban: 119125). After cancelling 'Edict of Nantes of 1598' French Protestants had lost their religious freedom. As a result France had become a fanatic country. Huge French Protestants had gone in various parts of Europe and beyond Europe to protect their 'Calvinist Protestantism,' many Protestants had to renounce their own religious belief Calvinist Protestantism and had to profess Catholicism reluctantly which they had abandoned before consciously. Voltaire was a daring writer; he could not tolerate hated 'Revocation of the Edict of Nantes' issued by Louis XIV of France by which religious freedom had been lost in France (Voltaire: 1-157, Hutton Webster: 360). Voltaire utilized his brave writing against religious superstition and fanaticism. He had shown in this book that how fanaticism had broken the French religious harmony established by the great king Henry IV. He had given a picture that how French Protestants were brutally tortured and rooted out from France by the then frenzied Catholics. He reviewed CatholicProtestant conflicts and its disastrous and terrible consequences in French society. Inspired by Voltaire's rational writings against religious intolerance and superstition; French revolutionaries were awakened and keenly desirous to establish religious harmony and to bring Catholic-Protestant in friendly terms in France. Revolutionaries had given complete religious freedom for French protestant constitutionally. So it is clearly perceived that revolutionaries were highly stimulated by Voltaire's above mentioned book. (Voltaire, Treatise on Tolerance: 1-157, Alfred Cobban: 83, Hutton Webster: 360, William Doyle: 55, R. R. Palmer, Joel Colton, Lioyd Kramer: 361, Mark Kishlansky, Patrick Geary, Patricia O’Brien: 580)

Voltaire was tortured by the suppressing French government in his whole life. He had close friendship with Frederick the Great (1740-1786), king of the kingdom of Prussia. Voltaire had lived in Prussia for several years under 
the patronization of Frederick the Great (R.R.Palmer: 302). But for many reasons their friendship had begun bitter and as a result Voltaire had to come back to Paris (Alfred Cobban: 121, Mark Kishlansky and others: 580). But then French king Louis XV did not allow him to live in Paris. In 1759, at last he had taken a decision to settle down in 'Ferney' which was located in eastern France. He lived there till his death (Jawaharlal Nehru: 438). Living in 'Ferney', he had completed a great task. In 1764, he published 'The Dictionnaire Philosophique'. 'The Dictionnaire Philosophique' is well known in English as 'The Philosophical Dictionary' in the whole world. This is a philosophical work and this was his lifelong work for which he had worked hard and for this hard work his health had begun to deteriorate. This 'The Dictionnaire Philosophique' was an encyclopedic dictionary and it was written in French language. In this dictionary he had written many articles on various subjects. Now the question is that what was the relation between 'The Dictionnaire Philosophique' and the French revolution. The relation is that Voltaire criticized against the Church's corrupted administrative system of France in this dictionary (Voltaire: 3-117, Alfred Cobban: 84). He had an incisive writing style. His style of criticism was striking; his extremely courageous system of writing had attracted the revolutionary leaders. He was annoyed to see the mismanagement of the church and he was able to express his disliking or hatred in this regard in his writing. He presented the unfair conduct of the church's dishonest administration. His trenchant views on religious dogmas were well expressed in this dictionary. He presented the real picture that French church officials had forgotten their real responsibilities. In the early history of French church the ecclesiastical officials were devoted to serve the destitute people. To perform the religious rituals properly and to do people's welfare was their prime duties. They were really altruist. Unselfishness was the main characteristic of their work. Simple-hearted religious people had relied on their simplicity, sincerity, honesty, kindheartedness and compassion. There was a time when simplehearted religious people had never thought to be deceived by the ecclesiastical officials of holy church. But gradually common people had begun to be cheated by the church's unethical officials. Ecclesiastical officials had begun engaged for protecting their self-interest. Instead of being altruist they had engaged themselves to realize their own interest. These madly self-seeking ecclesiastical officials were accomplishing their official duties to attain their worldly interests. They had become wicked and sinful (Mark Kishlansky and others: 579). They were betraying with the simple-hearted religious people. French church was the richest institution in France, whereas it was wealthiest so it was supposed to pay huge taxes but unfortunately it was true that French government did not get any tax from French church regularly. Reason was given from the Church authority that Church officials were always making effort for people's welfare so they should be exempted from taxpaying. So church was given exemption from taxpaying. In 1749 French government introduced a new tax titled 'Vingtieme,' government had decided that all people of France will have to pay $5 \%$ of their income regardless of their status. But after two years of its operation all clergies had begun agitation for the exemption from taxpaying. As a result then French government was compelled to exempt them from that taxpaying due to their irresistible movement. Voltaire was brave, rationalist and free thinker. Voltaire had watched their misdeed and hypocrisy. Their hypocrisy had made Voltaire wrathful and dissenting against church's defiled administration. 
With due deliberation he described that church officials had turned into deceivers and hypocrite. They were bearing and holding fanaticism and religious superstition. Church officials could not tolerate reasoning and free thought. They desired the ordinary people to be religiously superstitious. Voltaire wished church's officials to be altruist in their holy religious career. Voltaire tried to uphold the real spirit of the church by criticizing the church's dishonest officials. His efforts were effective. 'The Dictionnaire Philosophique' had come to the French people as an awakening book (Alfred Cobban: 119-125, Charles Downer Hazen: 83). People were in darkness; this dictionary had brought them to their senses. His writing was able to awaken its readers against the misdeed of the church's dishonest officials. Many enthusiastic readers of this dictionary was elected in the election of 1789 and had become the member of the French parliament. They were revolutionaries; they were motivated by the above mentioned dictionary and were very eager and determined to bring radical changes in French church administrative system during French revolution. Voltaire's writings had shown them that how church's hypocrite administrators were exploiting simple-hearted religious people. French revolutionaries were able to grasp that what Voltaire had conveyed about misled church administrators. Revolutionaries were able to grasp the importance of Voltaire's concern about French church system (Shepard B. Clough and others: 758, Georges Lefebvre: 166, W. Crawley (Ed.):146, William Doyle: 136, James Mathew Thompson: 29).

French revolution had lasted for ten years and six months. Revolutionary leaders brought many revolutionary changes in France. During French revolution revolutionary leaders had taken stern initiative against church's defiled officials. Because revolutionaries were impassioned about Voltaire's writings. They were educated and enlightened class. They were conscious about church and willing to reform church. On 12th July, in 1790, French National Assembly had passed a law titled 'Civil Constitution of the Clergy' to bring changes in the church administrative system (Shepard B. Clough and others: 758, William Doyle: 136, Robert Ergang: 635-638, R.R. Palmer and others: 361, W.Crawley:146, Albert Goodwin: 169, Georges Lefebvre: 166, J.M.Roberts:106, Peter Gay and R.K Webb: 474). By this legislation revolutionaries had made French church a civil institution. All landed properties, buildings, decorative materials and endowments of the church were declared confiscated, made nationalized and sold out. Tithe was a tormenting tax in France since 1585. French people had been afflicting for this torturing tax by French church. This tax was declared abolished. They reduced the number of Bishops and priests in churches. Since then the relationship of Pope and French church officials were very nominal. It was said in that law that all bishops will be selected by the active citizen of their own department. All church officials will be paid by the French treasury. Full religious freedom was given to French Protestants who were known as Huguenot in France. The entire church administrative system was brought under state control. He earnestly desired for religious liberty and 'French Constitution of 1791' granted complete religious freedom for French people. (R.R. Palmer and others: 358, Mark Kishlasky and others: 623, Petter Gay and R.K webb: 474, Shepard B Clough and others: 763, J.M Thompson: 27, George Lefebvre: 145, Philip Lee Ralph and Others: 202, C.W. Crawley (Ed): 146, Georges Lefebvre: 168, J.M.Roberts: 38, J.M.Thomson: 27, A.Goodwin: 681, Voltaire, Philosophical 
Dictionary: 1-116, Hays, Carlton J.H: 502, Jawaharlal Nehru: 424, James Edgar Swain: 475)

Above mentioned radical changes in French government, French ruling system and French church administration were unthinkable before the French revolution. Voltaire was a Great philosopher. He was against the mismanagement of the French ruling system and church administration. He wished French churches to be disciplined and in orderly manner. So in several ways he disclosed the corruptive administrative system of then French church. French revolutionaries were inspired and influenced by the writings of Voltaire which criticized church official's unethical activities and French ruling system. So revolutionaries abolished all unfair privileges of the church officials, changed French ruling system and introduced constitutional monarchy. He did not use the word 'Revolution' in any of his works. But the way he had written against church's corrupted officials that were revolutionary. He had not called for revolution but which he had written was revolutionary. All activities of church were expected to accept without argument in French society before the French revolution; but he had written against all hypocrisies of church officials which was a risky and dangerous task for him. After publishing his 'Letters Philosophiques' he had lost his right to live in Paris which was his birthplace. But this cruel punishment could not stop his boldness and venture. He stayed in 'Ferney' in Eastern France and continued his courageous writing against hollow administrative system of church throughout his life. Later on this 'Ferney' town was renamed as 'Ferney Voltaire' after him by the revolutionaries. So this is clear that French revolutionaries were deeply influenced by the overall works of Voltaire. He left this world eleven years before the French revolution. After his death he was buried in
Champagne (At present part of Grand Est region of northeastern France). During French revolution his bones were brought and laid to rest in the Pantheon, a grand mausoleum in Paris, France, where the national heroes of France were buried. It was an honor for him. Revolutionaries of France considered Voltaire as a national hero. He was not alive on the eve of the French revolution, despite his death eleven years before the French revolution his influence was still in the minds of the revolutionaries. French Revolution and Voltaire cannot be separated. So, this is undeniable that Voltaire's works had extended its profound influence in the mind of the revolutionaries of the French revolution.

\section{References}

A. Goodwin (ed), The New Cambridge Modern History, The American and French Revolutions (1763-1793), Vol. viii, Cambridge University Press, London, 1968.

Albert Goodwin, The French Revolution, Harper Collins Publishers Ltd, New York, 1966.

Aldridge, Alfred Owen, Voltaire and the Century of Light, Princeton, NJ: Princeton University Press, 1975.

Alfred Cobban, A History of Modern France, Vol.1, Pengoin Books Ltd, Victoria, 1961.

ALFRED COBBAN, In Search Of Humanity, The Role of the enlightenment in Modern History, ALFRED COBBAN, George Braziller, Inc. 215 Park Avenue South, New York.

Ayer, AJ, Voltaire, New York City, Random House, 1986.

C. W. Crawley (Ed), The New Cambridge Modern History volume. 9. War and Peace, in an age of upheaval (1793-1830), Cambridge, At the University Press, 1969.

Charls Downer Hazen, Modern Europe upto 1945, S. Chand and Company Ltd., Ram Nagar, New Delhi, 1983. 
Georges Lefebvre, The French Revolution: From its Origins to 1793, Vol-1, Columbia University Press, New York, 1962.

Hayes, Carlton J.H, Modern Europe to 1870, The Macmillan Company, New York, 1953.

Hutton Webster, World History, D.C.HEATH and CO. 2 B 2, 1921.

J.M. Roberts, The French Revolution, Oxford University Press, London, 1978.

James Edgar Swain, A history of world civilization, Second Editioon, Eurasia Publishing House (PVT) Ltd. Ram Nagar, New Delhi, 1947.

James Matthew Thompson, Robespierre and the French Revolution, Collier Book, New York, New York, 1962.

Jawaharlal Nehru, Glimpses of World History, Penguin Books India Pvt. Ltd, 11 Community Centre, Panchsheel Park, New Delhi 110 017, India, 2004.

Mark Kishlansky, Patrick Geary, Patricia O’Brien, Civilization in the West, From The Renaissance to the Present, Second Edition, Harper Collins college publishers, 10 east 53rd Street, New York, NY10022, 1995.

Mason, Haydn, Candide: Optimism Demolished, Twayne's Masterwork Studies, Twayne Publishers, New York City, 1992.

Petter Gay and R.K. Webb, Modern Europe to 1815, Harper and Row Publishers, New York, Evanston, San Francisco, London, 1973.

Philip Lee Ralph, Robert E. Lerner, Standish Meacham, Alan T. Wood, Richard W. Hull, Edward McNall Burns, World Civilizations, Their History and Their Culture, vol.-2/Ninth Edition, Publisher: W.W. Norton and Company, New York, London 1993.
Prafulla Kumar Chakrabarti, Pharashi Biplob, West Bengal State Book Board, 6A, Raja Subodh Mallik Square, Kolkatta, 2000.

R.R. Palmer, Joel Colton, Lioyd Kramer, A History of the Modern World, Ninth Edition, McGraw-Hill, McGraw-Hill Companies, Inc. 1221, Avenue of the Americas, New York,10020, 2002.

Robert Ergang, Europe: from the Renaissance to Waterloo, Published in 1939 by D,C Heath and Company, 125 Spring Street, Lexington, Massachussetts, USA.

Shepard B. Clough, David L. Hick, David Brandenburg Peter Gay, A History of the Western World, Early Modern Time, D, C Heath And Company, Boston / Englewood / San Francisco / Chicago Atlanta / Dallas / London / Toronto, 1965.

The History of Peter the Great, Emperer of Russia, From the French of Voltaire by Smollett, Vol., New York: Leavitt and Allen, Broadway, 1857.

Voltaire, Letters Concerning the English Nation, Oxford University Press, Great Clarendon Street, Oxford OX 2 6DP

Voltaire, PHILOSOPHICAL DICTIONARY, A COMPENDIUM EDITED AND TRANSLATED BY WADE BASKIN, PETER OWEN LIMITED, 50, Old Brompton road London, SW7, British Commonwealth edition, 1962.

Voltaire, Treatise on Tolerance, Translated by Brian Mastars, The Pit Building, Trumpington Street, Cambridge, United Kingdom, Cambridge University Press, 2000.

William Doyle, The Oxford History of the French Revolution, Second Edition, Oxford University Press, Great Clarendon Street, Oxford OX 2 6DP, 2002.

Williams, David, Voltaire: "Candide”, Spain Grand and Cutler Ltd. 1997. 